\title{
Motivational and Contextualization Actions in Initial Series (Freshmans) of the Undergraduate Biochemical Engineering Course
}

Denise da Fontoura Prates*

*Escola de Química e Alimentos, Universidade Federal do Rio Grande, Rio Grande, Brazil. E-mail: denisefprates@gmail.com

Gisele Medianeira Barbieri Moro

•Escola de Química e Alimentos, Universidade Federal do Rio Grande, Rio Grande, Brazil. E-mail: giselebarbieri_@hotmail.com

Ligia Machado Prieto^

`Escola de Química e Alimentos, Universidade Federal do Rio Grande, Rio Grande, Brazil. E-mail: ligiaprieto@yahoo.com.br

\section{Diovana T Franck}

'Escola de Química e Alimentos, Universidade Federal do Rio Grande, Rio Grande, Brazil. E-mail: diovanafranck@gmail.com

Michele da Rosa Andrade Zimmermann de Souza ${ }^{\circ}$

${ }^{\circ}$ Escola de Química e Alimentos, Universidade Federal do Rio Grande, Rio Grande, Brazil. E-mail: michrandrade@gmail.com 
Jorge Alberto Vieira Costa $a^{\text {ø }}$

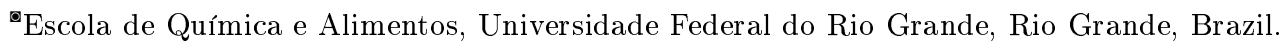

E-mail: jorge@pq.cnpq.br

\begin{abstract}
The focus of this work was to present the activities carried out with the first and second semester students of the Biochemical Engineering (EB) undergraduate course of the Federal University of Rio Grande (FURG) through actions related to the Project "Contextualization of Basic Disciplines and Motivation of the initial series of the courses of Food Engineering and Biochemical Engineering: meeting an old and a current demand", of the Program of Support to Restructuring and Expansion Plans of Federal Universities. The following activities were carried out: Cycle of Lectures; Lectures of graduated of Engineers working in the field; Computer Tool Workshops; Scientific Research Workshops; Seminar Presentations, Application of study tutorials; Surveys, among others. These activities contributed to motivation and expansion on the knowledge about course, and also contextualized practices that are explored. throughout the academic activities. The actions developed in this work can be reproduced in other courses and educational institutions in the fight against demotivation, dropouts and retention.
\end{abstract}

Keywords: Dropout, Education, Biochemical Engineering, Student motivation, Undergraduation.

\title{
1. Introduction
}

In the last decade, access to Higher Education has increased due to the expansion of the number of seats in Federal Universities, number of courses and number of Campuses, as well as programs to stimulate students to stay enrolled in their courses. Nevertheless, high drop-out and retention rates have been recorded, especially in Engineering courses, highlighting these problems, more markedly in freshmen ${ }^{1}$.

The lack of contextualization between the syllabus of the basic classes and their possible applications during the undergraduate course is an old problem in the subjects of initial series of Engineering courses, which can lead to the decrease of the interest of some students. Adding to this problem, there is the lack of basic knowledge brought from high school, which may result in an aggravating factor for failures and dropouts ${ }^{1,2,3}$.

The possibility of promoting the contextualization of the initial series disciplines, demonstrating application within the more advanced disciplines of the course itself and in problem situations of professional life, gives meaning to the content that students are learning. Even for those students who obtain approval in the disciplines of the initial semesters, they could potentiate their performance during the course if basic knowledge was contextualized, preparing for the application of this learning in later semesters and in the future profession $^{4}$.

The personal motivation of the incoming student can be another vector that drives them to University failure. According to Bazzo ${ }^{5}$, "the entrance gates of a University course separate two worlds that are unknown". For these authors, the arrival in an Engineering course at the University is like "embarking on a moving vehicle, which already has an old and consolidated trajectory, which functions as a wellstructured system with characters occupying their positions in the seats and it is not as easy as it seems". In this context, 
motivational actions to mediate this stage can minimize the impact of the change and keep the student motivated during this initial period of great difficulties.

Teaching projects can be decisive in this early stage of academic life, modifying attitudes to positively affecting learning. The implementation of these projects was encouraged at the beginning of this decade, for example, through the scholarship announcements of the "Program of Support to Restructuring and Expansion Plans of Federal Universities", with funding scholarships to graduate students to develop actions aiming to improve quality in undergraduate education ${ }^{6}$.

The course of Biochemical Engineering at FURG has begun to be offered in 2010 and because several professors of the course work in the Postgraduate Program in Food Science and Engineering (PPG-ECA) there has always been a strong interaction between undergraduate and graduate courses, which occurs mainly through the implementation of teaching, research and extension projects. Previous experience of the professors of the undergraduate course in Biochemical Engineering, with the support of graduate scholarship holders of the PPG-ECA in the project entitled "Contextualization of basic subjects and motivation of the initial series of the courses of Food Engineering and Biochemistry: meeting to an old and a current demand", contributed to intensify actions in favor of a qualified formation, through the contextualization of disciplines of the initial series and of motivational actions for freshmen.

Based on the foregoing considerations, the objective of this work was to present the activities developed during the project "Contextualization of basic disciplines and motivation of the initial series of the courses of Food Engineering and Biochemistry: meeting an old and a current demand", in order to reach the initial series of the course of Biochemical Engineering course of FURG with motivational and contextualization actions.

\section{Work Development}

The actions were organized and carried out by 8 Postgraduate Fellows (4 Reuni and 4 volunteers) together with their advisors and with the support of the Coordinator of the Biochemical Engineering course. These actions were directed to first and second term students of the Biochemical Engineering course in 2010. The project "Contextualization of basic disciplines and motivation of the initial series of Food Engineering and Biochemistry courses: meeting an old and a current demand", included two undergraduate courses, Biochemical Engineering and Food Engineering, however, this manuscript refers to the activities directed to the course of Biochemical Engineering. Therefore, the project was initially divulged by the professors and fellows in the classes of Biochemical Engineering, emphasizing that the schedule of activities would be adjusted to the students' vacant schedules and to the availability of the project executors in order to reach the largest number of participants in the activities. These activities are described and discussed below.

\subsection{Cycle of Lectures in the Course of Fundamentals of Engineering Biochemistry I}

A Cycle of Lectures was held with the purpose of addressing several topics for contextualizing the subjects of the initial series and to motivate the students of the first semester of the course. The lectures were given by professionals in the area of Biochemical Engineering or by professors of the School of Chemistry and Food of FURG, who offer courses for Biochemical Engineering and/or develop teaching, research or extension related to this field of knowledge. The topics covered in the lectures were: Job opportunities in Biochemi- 
cal Engineering; General aspects of the Biochemical Engineering Course; Nomenclature in Biochemical Engineering; Biomolecules; Systemic thinking; Operations in Biochemical Engineering; Instrumentation and Process control; Enzymes and Bioremediation; Experimental Teaching of Unitary Operations; Integration between Chemical and Biochemical Engineering; Enzymatic Synthesis and Cultures to obtain Bioproducts; Recovery and Purification of Bioproducts; Biosurfactant and Bioremediation; and Obtaining a Hydrogel from corvine proteins (Micropogonias furnieri) and solubility of the residual proteins. At the end of each lecture, the students had to write a summary of the lecture attended. After the closing of all the lectures, at the end of the semester, the students answered a survey, to evaluate the performed activities.

\subsection{Lectures Given by Engineers from FURG}

The topics covered in the lectures were: Administration of academic life; Application of the basic classes in more advanced subjects of the course and in the professional activity; Ex-student conception; Presentation techniques of scientific works; Retrospective of subjects related to Engineering and presentation of current topics in education, discussed at the XXXIX Brazilian Congress of Engineering Education (COBENGE). The lectures were organized by the scholarship holders of the project and provided an exchange environment that brought experiences lived by graduated professionals working in several areas.

\subsection{Workshop on Research of Bibliographic Material}

This workshop addressed the research of books using the Sistema de Bibliotecas (SIB) of FURG, research of available e-books in the library, research of scientific papers in the Coordenação de Aperfeiçoamento de Pessoal de Nível Superior (CAPES) Portal of Journals and how to use databases like Science Direct, Scielo, among others, patents and technical standards of Associação Brasileira de Normas Técnicas (ABNT).

Topics such as the definition of scientific research, methods for surveying and selecting bibliographic material and the importance of research in reliable databases were addressed. Another topic highlighted was the legal and ethical implications of plagiarism in order to make students aware of this harmful practice, which is increasing in undergraduate courses and graduate programs.

\subsection{Workshop on How to Write Reports and Scientific Papers}

This workshop addressed topics required for writing high quality academic papers, especially reports of practical classes, which were requested by students throughout the course. Prior to the workshop, professors from major classes who teach practical classes needed to get together to set standards to be used in the reports, so these standards would be unified for writing reports in their classes. It was approached how to write each topic, such as abstract, introduction, justification, objectives, material and method, results, discussion and conclusion $^{4}$. The workshops aimed to contribute for the improvement of the papers quality that would be elaborated later, not only in the classroom, but also in scientific writing.

\subsection{Workshops on Basic Computational Tools}

Post-Graduate scholarship holders offered two workshops, one about the use of text editors (Word) and another on slide presentation in PowerPoint. These workshops were 
carried out in a computer lab. In workshop of Microsoft Word, several functions of this tool were explained, including creating texts, tables, graphics, images, printing, using shortcuts, saving documents, and mainly formatting documents ${ }^{7}$.

The workshop on creation, editing and slide presentation tool "PowerPoint" was offered to teach and to answer questions about the use of this resource that is widely used in presentations of academic papers, as well as in scientific conferences. We have demonstrated creation/editing and presentation of slides, how to use resources of images, sounds, texts and videos that can be animated and controlled in different ways ${ }^{8}$.

In these workshops were presented several functionalities of computational tools for the creation of texts, tables, formatting and oral presentations of works that will be required throughout the undergraduate course and probably during the professional life of the Engineer.

\subsection{Elaboration and Presentation of Seminars by Students of the Initial Series}

The students of the second semester were divided into groups of two or three components. They had to chose a topic related to the future profession of Biochemical Engineer and, under the guidance of a professor, they elaborated and presented their chosen topic in a seminar. Students had to follow writing and presentation standards, presentation time, applying computer tools learned in the previous workshop. Although computer tools are common use for many, some students had their first contact with these resources at the University.

The preparation and presentation of seminars by the students of the initial series was developed in the class of Fundamentals of Biochemical Engineering II (second semester of the course). This activity was planned for the students because they would be able to apply the knowledge that they have acquired in the workshops. The workshops "Elaboration of reports and scientific works", "Research of Bibliographic Material" and "Word Text Editor", would be useful for the written part of the seminar. In addition, the teachings of the "Power Point Workshop" would assist the class in the construction of the multi-media presentation of the seminar.

The work included a written part on the subject that was due thirty days before the presentation date according to previously standards established to seminar. The time for oral presentation ranged from 20 to 30 minutes. The work of each group was presented to the rest of the class, who asked questions at the end of the presentation and to a group of three professors, who, besides evaluating the work and presentation of the group, made final considerations to the presentations, highlighting positive and/or negatives points. Considerations such as time, group organization, posture and language, quality of content and slides, attendance to pre-established standards and answers to questions after the presentations were items evaluated by the professors. Because the presenters were first-semester students not technical and scientific aspects, which would still be addressed thoroughly throughout the course, were not evaluated. The topics presented were: Microalgae; Genetic Engineering; Purification of bioproducts; Wastewater treatment; Biogas; Bioremediation; Biosurfactants; Biopolymers; Beer; Vaccines; Wine; Biocosmetics; Antibiotics and Enzymes. At the end of all the presentations, the students answered a survey to evaluate this activity.

\subsection{News Archive and Formation of the "News Discussion Group"}

The preparation and maintenance of the news archive consisted in the selection of news 
media (newspapers, websites, technical journals, etc.) by the graduate students of the project. The news archive was organized by e-mail, and all freshmen (first and second periods) of the Biochemical Engineering course had access to the collection. The selected articles involved applications of the basic classes and relevant topics of Biochemical Engineering including algae for the production of bioethanol, artificial photosynthesis and training of Engineers in Brazil. This practice aimed at updating and understanding the social insertion of engineers as agents in the local, regional, national and global scenario.

The news in the collection that got more votes among student preferences was chosen to be discussed in the so-called "News Discussion Group". Additional news of student interest that were not included in the collection could also be taken by the student to the Group.

The operation of the Discussion Group was designed so that each student would have about 10 minutes to read and think about the news and then present to the rest of the group, which was composed of other students of Biochemical Engineering, graduate students of the project and professors. In this way, a debate and interaction of all participants was promoted in order to update, reflect and form an opinion about what was being debated.

\subsection{Studying Tutorials for Specific Classes}

Studying guides were developed by the graduate students to assist in the disciplines of General Microbiology, Biochemistry and Calculus I and II. The tutorials were built from the class syllabus, presenting a summary of the content covered in each subject, contextualized exercises and examples of application of content in Engineering problems. The tutorials were made available to students through the Moodle platform. The topics covered in each class were: (1) General Microbiology: introduction to general microbiology; polarity and chemical composition of microorganisms; importance of the structure of microorganisms; cell wall of prokaryotic organisms; structure of eukaryotic organisms; nutrient requirements for growth of micro-organisms and viruses; (2) Biochemistry: water; carbohydrates; amino acids and peptides; proteins; lipids; enzymes; introduction to metabolism; carbohydrate metabolism; electron transport chain; oxidative phosphorylation; lipid metabolism; nitrogen metabolism; photosynthesis; (3) Calculus I: limits and continuity; derivative, integral and functions; (4) Calculus II: numerical sequences; numerical series; differential equations and Laplace transforms.

\section{Results and Discussion}

The activities carried out as part of the project "Contextualization of basic subjects and motivation of the initial series of Biochemical Engineering courses: meeting an old and a current demand" provided a positive reflection, through the academic performance of the freshmen students. Positive results were observed by the professors, who received from the students, well-written papers and reports with adequate formatting, use of reliable scientific sources, clearer and dynamic seminar presentations, positioning and reflection of news that regard the universe of the Engineer. Besides that, contextualization of subjects that will be further developed throughout the undergraduate course.

According to $\mathrm{Gil}^{9}$, it is important that professors know: recognize factors that will interfere with student motivation; identify procedures that contribute to the greater benefit of reading; identify procedure for problem solving; define procedures for the preparation of written papers and decide on laboratory experiments ${ }^{9}$.

From the activities developed in the "Cycle of Lectures" and "Lectures given by FURG graduates" it is possible to emphasize that the lectures contributed to the increase of know- 
ledge and interest in the course of Biochemical Engineering. Of the thirty-four students in the first semester of the Biochemical Engineering course, who answered the questionnaire about the cycle of lectures, $100 \%$ indicated that they liked this activity and $100 \%$ considered that the Lecture Cycle contributed to increase their knowledge about the course. In relation to the score of $0-10$, which the participants attributed to the Lecture Cycle, 8.05 was the average of the grades assigned by the 34 students.

At the end of the lectures the students were encouraged to question the speakers. Regarding the importance of these questions, most of the students (Graphic 1) emphasized that it was important, since it was possible to ask questions that arose during the lecture.

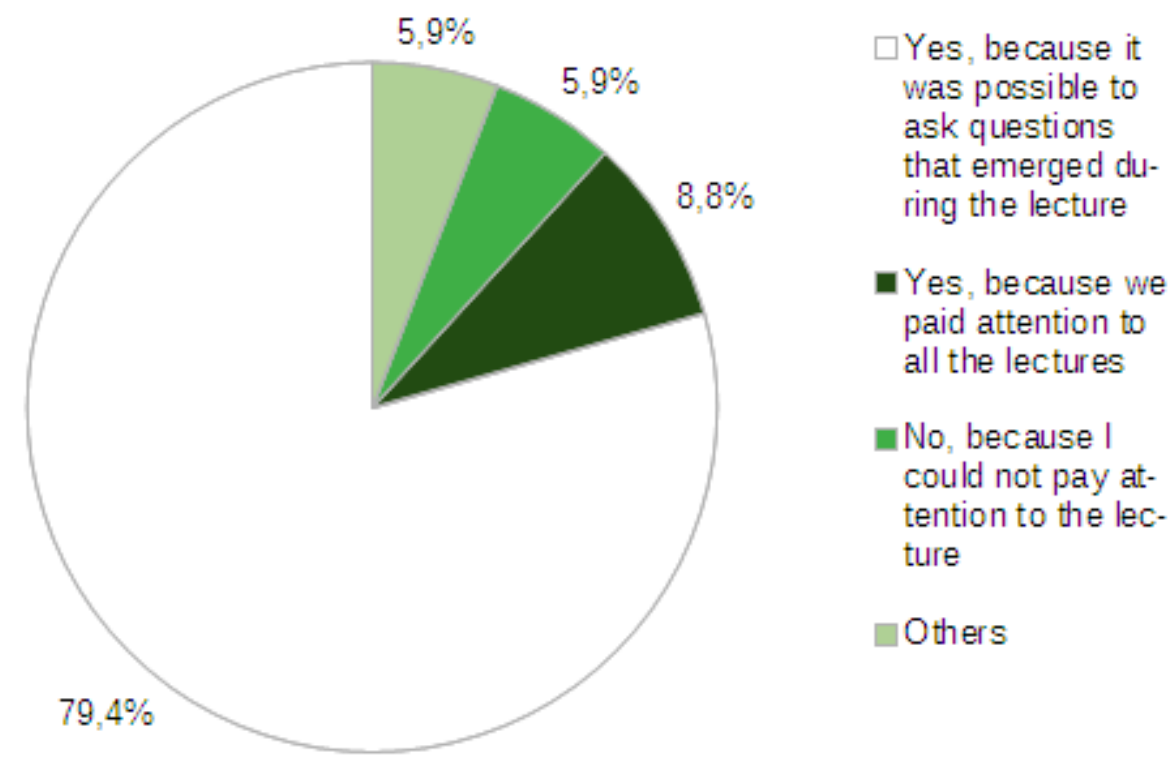

Graphic 1. Answers to the question "Did you find it important to ask questions after the lectures?".

Regarding any difficulties faced by the students while writing the abstracts of the lectures (Graphic 2), the majority pointed out that "Yes", since they did not have sufficient knowledge about the contents of the abstract.

Regarding the participation of the class in the Cycle of Lectures, $79.4 \%$ of the students considered the participation to be "good"; $11.7 \%$ considered it "excellent" and $8.8 \%$ considered that "it could be better". With respect to the grade (0-10) that each student assigned according to his participation in the Lecture Cycle, it was observed that on average, the self-assessment grade was 8.0 Finally, of the 34 students who answered the survey, $100 \%$ considered that the Cycle of Lectures should be carried out for the next freshmen of Biochemical Engineering.

It is also worth noting that lectures with the participation of graduated Engineers in areas of interest to the course of Biochemical Engineering is of fundamental importance since the reports of professionals already in the labor market increase the general vision of the future profession. 
Regarding to "Elaboration and presentation of seminars by the students of the initial series", 13 seminars with different topics were presented, so that students could include bibliographical research paper under the guidance of professors, seeking basic, technical and scientific information. Developing an appropriate posture and overcoming shyness are not easy tasks for many newcomers. Through the presentation of the seminars, students were able to come across the practice of public speaking and reflect on the importance of communication in a clear and concise way on a topic related to their major.

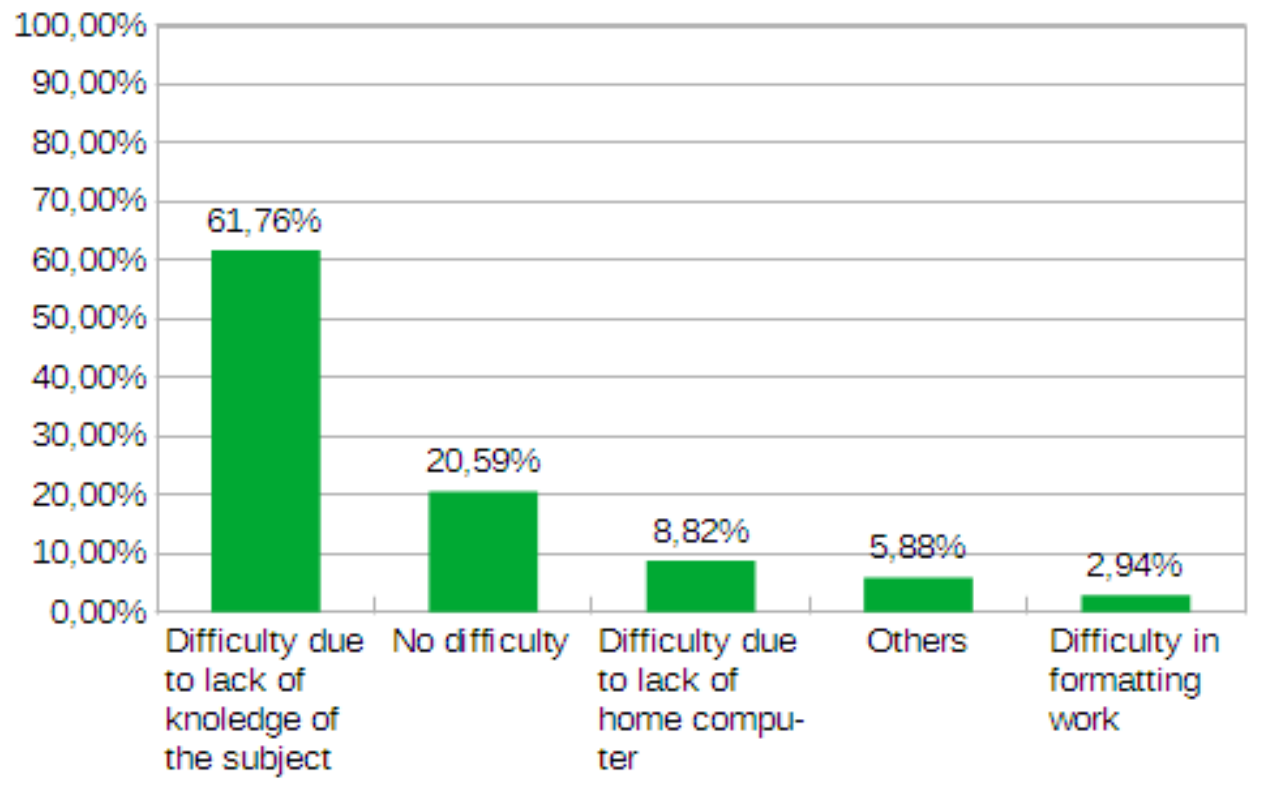

Graphic 2 . Answers to the question "Have you faced any difficulties in writing the abstracts?".

Concerning the questions about the seminar activity, the questions that were asked: "Did you like the seminar activity?" "Do you think the seminars contributed to increase your knowledge about the course and the profession of Biochemical Engineer?" And "A seminars should be carried out with the next classes of Biochemical Engineering?", as a response $97.0 \%$ of the 34 students considered the "Yes" answer for these three questions while $2.95 \%$ considered the answer "No".

When asked if the student considered it important to ask questions at the end of the seminars, the percentage of the responses indicated was $91.17 \%$ for the answer "Yes, because this way we can ask questions that arise during the presentation", $2.94 \%$ was pointed out for the answers "No, because I could not pay attention to the seminar"; "Yes, because we pay attention to the whole presentation" and "others".

When questioned about the difficulty face on writing the seminars, $44.1 \%$ said they did not have any difficulty, $26.5 \%$ considered having difficulty in their knowledge, $11.7 \%$ presented difficulties in formatting work and $5.9 \%$ had in difficulty writing.

Concerning the difficulty of the students in the presentations of the seminars, $42.8 \%$ said they did not have difficulty, $37.1 \%$ considered having difficulty, and this was related to the difficulty in speaking in public, $11.42 \%$ attributed their difficulty in presenting seminars by speaking about the covered subjects and $8.6 \%$ considered other difficulties. 
The "news discussion" activity contemplated the scientific and social dimensions, which may have awakened the critical capacity and motivation of the student, since many students perceive the importance of their profession in society and how the knowledge built in the University can help to solve problems, opening up professional opportunities.

The contributions obtained through the workshops of "Basic computational tools", "Research of bibliographical material" and "Elaboration of reports and scientific papers", stood out because they helped positively in the way of proper use of text editors and creations/editions of presentations, assisting in the quality and agility of preparing the papers. Even though there was no quantitative evaluation of the impact of the workshops on student performance, the teachers participating in the project perceived and reported improvements in the writing of practical reports, scientific papers and presentations of the students.

The use of study tutorials served as support for studies, for learning concepts and for demonstrating topics related to daily life. In addition, the preparation of the tutorials made it possible for graduate students to improve their studies skills.

The practices of contextualization and motivation made possible the interaction between professors, advisors and undergraduate and graduate students.

\section{Final Considerations}

The activities carried out contributed to the motivation and contextualization of the initial series of the Biochemical Engineering course. These actions generated a rich environment for exchanging experiences among all involved: coordination and professors of the Biochemical Engineering course, undergraduates, graduate students and professionals.

The activities developed can broaden the knowledge about the course and also provide a basis for practices that are explored throughout academic activities, such as construction of scientific papers, critical analysis, development of exercises and seminar presentations. In addition, they prepare the student to cope with shyness and develop a proper posture for public speaking. Therefore, the actions developed in this work can serve as an incentive for other courses and educational institutions that are concerned with motivating students and ultimately, contribute to the fight against the complex problem of dropouts and retention ${ }^{10}$.

\section{Acknowledgment}

The authors thank the Graduate Program in Food Engineering and Science (GPFES) and CAPES for the graduate Reuni scholarships, both of which contributed to the incentive and accomplishment of this work and other project collaborators.

\section{References}

1. FILHO, R. L. L. S.; MONTEJUNAS, P. R.; HIPÓlitO, O.; LOBO, M. B. C. M. A evasão no ensino superior brasileiro. Cadernos de Pesquisa, v. 37, n. 132, p. 641-659, 2007.

2. INEP. Instituto Nacional de Estudos e Pesquisas Educacionais Anísio Teixeira. Avaliação de Cursos de Graduação presencial e a distância. Disponível em: http://www.inep.gov.br. Acesso em: 18 jan. 2016.

3. MOREIRA, J. B.; PRATES, D. F.; RADMANN, E. M.; COSTA, J. A. V.; MORAiS, M. G. Auxílio à aprendizagem associado à aula prática em disciplina do curso de Engenharia Bioquímica. Revista Eletrônica Engenharia Viva, Goiânia, v. 1, p. 30-35, 2016. 
4. MORO, G. M. B.; PRIETO, L. M.; PRATES, D. F.; SOUZA, M. R. A. Z.; COSTA, J. A. V. Ferramentas computacionais para séries iniciais de engenharia: abordagem em oficinas extraclasse. In: CONGRESSO BRASILEIRO DE EDUCAÇÃO EM ENGENHARIA, 40., 2012, Belém. Proceedings... Belém: UFPA, 2012. Available in: http://www.abenge.org.br/cobenge/arquivos/7/artigos/104495.pdf.

5. BAZZO, W. A.; PEREIRA, L. T. V. Introdução à Engenharia: Conceitos, Ferramentas e Comportamentos. Santa Catarina: UFSC, 2006.

6. BRASIL. Ministério da Educação. Portaria ${ }^{\circ}$ 582, de 14 de maio de 2008. Disciplina a concessão das bolsas de pós-graduação previstas no Reuni. Publicada no Diário Oficial da União - DOU $\mathrm{n}^{\circ}$ 92, Seção I, de 15 de maio de 2008.

7. MICROSOFT® WORD, 2007. Disponível em: http://www.microsoft.com.br.

8. MICROSOFTR POWERPOINT, 2007. Disponível em: http://www.microsoft.com.br.

9. GIL, A. C. Didática do Ensino Superior. São Paulo: Atlas, 2013.

10. SILVA, G. G. A. et al. Methods to Increase Freshmen Interest and Motivation: Combating Retention and Evasion Among Biochemical Engineering Students. In: DEUS JÚNIOR, G. A. de et. al. (Org.). Alive Engineering Education. Goiânia: Cegraf UFG, 2017. cap. 37, p 369-376. Available: < https://icaeedu.emc.ufg.br/p/22211-alive-engineering-educationtransforming-and-innovating-engineering-education $>$ Date of acess: 10 Sept. 2018. 